\title{
STUDI PERENCANAAN PENGEMBANGAN KAWASAN TERNAK DI KABUPATEN PAMEKASAN
}

\author{
Taufik Rahman \\ Badan Penelitian dan Pengembangan Daerah Kabupaten Pamekasan \\ Jl. Jokotole No 02 Pamekasan Madura \\ taufik.balitbang@yahoo.co.id
}

\begin{abstract}
ABSTRAK
Kabupaten Pamekasan dikenal sebagai salah satu daerah penghasil ternak di Madura. Berdasarkan data BPS, pada tahun 2015 jenis ternak yang banyak ditemukan antara lain didominasi oleh sapi potong, kambing, domba dan ternak unggas. Namun persebaran kawasan peternakan di Kabupaten Pamekasan tidak begitu merata. Hal ini diduga disebabkan oleh beberapa faktor, antara lain faktor geografis wilayah, faktor sosial dan faktor ekonomi. Studi pengembangan kawasan berbasis peternakan di Kabupaten Pamekasan ini bertujuan untuk : (1) Memetakan sebaran kawasan peternakan di Kabupaten Pamekasan berdasarkan jenis ternak dan letak geografisnya; (2) Mengumpulkan dan menganalisa data perkembangan usaha peternakan di Kabupaten Pamekasan; (3) Mengidentifikasi permasalahan dalam menjalankan dan mengembangkan usaha peternakan; (4) Menganalisa kawasan yang berpotensi untuk dikembangkan menjadi kawasan berbasis peternakan. Berdasarkan perhitungan nilai IDD, dari 13 kecamatan di Kabupaten Pamekasan, hanya 1 kecamatan yaitu Tlanakan yang memiliki status rawan (nilai IDD<2) untuk daya dukung peternakan. Sementara itu, wilayah kecamatan lainnya memiliki status aman (nilai IDD>2). Hal ini menunjukkan bahwa ternyata sebagian besar wilayah Kabupaten Pamekasan sesuai untuk dikembangkan sebagai kawasan peternakan bila ditinjau dari ketersediaan hijauan pakan. Berdasarkan nilai IDD, maka direkomendasikan bahwa wilayah yang sesuai untuk dikembangkan sebagai kawasan berbasis peternakan adalah Kecamatan Batumarmar, Galis dan Pademawu.
\end{abstract}

Kata Kunci : Peternakan, Sapi, Pamekasan, Daya Dukung

\section{PENDAHULUAN}

Target Utama Pembangunan Pertanian 2010 - 2020 terdiri dari Empat hal, yakni : a) Pencapaian Swasembada dan Swasembada Berkelanjutan, b) Peningkatan Diversifikasi Pangan, c) Peningkatan Nilai Tambah, Daya Saing dan Ekspor serta d) Peningkatan Kesejahteraan Petani. Keempat sasaran program ini sesuai dengan permasalahan yang dihadapi di dalam negeri, antara lain kejadian rawan pangan yang semakin meluas, perkembangan agribinis yang belum mampu membangun daya saing yang tinggi dan gagal memanfaatkan keunggulan komparatif yang dimiliki. Pada sisi lain, konsumsi pangan sebagian masyarakat yang berpendapatan menengah dan tinggi terus mengalami pertumbuhan. Indonesia terpaksa mengimpor komoditas pangan dalam jumlah relatif besar seperti beras, jagung, kedelai, daging dan susu untuk memenuhi kebutuhan masyarakat.

Penataan ruang untuk suatu penggunaan tertentu tidak hanya diperlukan bagi pemanfaatan oleh manusia saja, tetapi usaha-usaha yang berkaitan dengan manusia yang menggunakan potensi ruang juga perlu ditata, agar terjadi keseimbangan dan keharmonisan. Apalagi kegiatan-kegiatan yang juga melibatkan makhluk hidup yang jelas sangat tergantung dengan keberadaan ruang sebagai lingkungan hidupnya, seperti halnya dengan kegiatan peternakan, yang cenderung untuk disebarkan dan dikembangkan. Peternakan merupakan penghasil utama protein hewani yang sangat dibutuhkan masyarakat, yang 
dalam pembudidayaannya membutuhkan tanah/lahan dan air. Penatagunaan tanah dan air untuk berbagai kegiatan pembangunan, termasuk untuk kegiatan peternakan, sangat diperlukan agar dapat dicapai optimasi dalam pemanfaatan tanah/lahan dan air, serta sekaligus untuk mengurangi konflik dalam penggunaan tanah/lahan dan air untuk berbagai kegiatan pembangunan (Sitorus et al. 1997).

Dalam Keputusan Menteri Pertanian No :417/Kpts/OT.210/7/2001 telah disebutkan bahwa lokasi penyebaran dan pengembangan ternak adalah suatu tempat di wilayah penyebaran dan pengembangan ternak, terdiri dari satu desa atau lebih dalam satu kecamatan yang diprioritaskan untuk penyebaran dan pengembangan ternak. Kawasan penyebaran/pengembangan peternakan adalah konsentrasi penyebaran dan pengembangan peternakan yang terdiri dari beberapa lokasi dalam satu kabupaten. Wilayah penyebaran dan pengembangan ternak adalah suatu kawasan yang potensial untuk penyebaran dan pengembangan ternak yang terdiri dari satu kabupaten atau lebih dalam satu propinsi.

Penyebaran dan pengembangan ternak di daerah bertujuan untuk membentuk kawasan peternakan, keseimbangan pembangunan antar wilayah, optimalisasi sumberdaya untuk meningkatkan pendapatan peternak, populasi dan produksi, dalam rangka pemberdayaan masyarakat peternak. Menurut Kuswandi (1995), konsep tata ruang dalam suatu usaha peternakan adalah konsep pengelompokan aktivitas usaha ternak dalam ruang, sehingga setiap wilayah memiliki pusat-pusat usaha ternak yang didukung oleh daerahdaerah sekitarnya.

Kawasan peternakan merupakan salah satu bentuk dari penggunaan kawasan budidaya dalam struktur ruang suatu wilayah, yang dapat berupa kawasan budidaya yang diatur atau kawasan budidaya yang diarahkan (Faisal,2006). Kawasan budidaya yang diatur adalah tempat manusia beraktivitas dengan batasan-batasan tertentu. Batasan itu dapat berupa jenis kegiatan, volume, ukuran, tempat, atau metode pengelolaannya. Berbeda dengan kawasan yang diatur, cara pemanfaatan lahan yang diarahkan tidak dinyatakan dengan tegas, bahkan pengarahannya sering dilakukan secara sektoral (Hardjowigeno dan Widiatmaka, 2001).

Kabupaten Pamekasan dikenal sebagai salah satu daerah penghasil ternak di Madura. Berdasarkan data BPS, pada tahun 2015 jenis ternak yang banyak ditemukan antara lain didominasi oleh sapi potong, kambing, domba dan ternak unggas. Semenjak 5 tahun terakhir dapat diamati bahwa telah terjadi peningkatan jumlah hewan yang cukup signifikan untuk setiap jenis. Contohnya adalah ternak sapi potong yang pada tahun 2006 berjumlah 97.803 ekor, meningkat hampir 30\% menjadi sekitar 123.597 ekor pada tahun 2009. Hal ini menunjukkan bahwa usaha peternakan apabila dikelola dan dikembangkan dengan baik dapat menjadi sekitar yang penting dalam mendukung perekonomian Kabupaten Pamekasan.

Namun persebaran kawasan peternakan di Kabupaten Pamekasan tidak begitu merata. Hal ini diduga disebabkan oleh beberapa faktor, antara lain faktor geografis wilayah, faktor sosial dan faktor ekonomi. Faktor geografis wilayah memiliki peranan penting dalam persebaran kawasan ternak ini. Faktor ini mempengaruhi ketersediaan pakan dan juga kebutuhan ruang dalam pengembangan usaha peternakan.

Pembangunan peternakan merupakan salah satu aspek penting dalam pembangunan pertanian, terutama untuk mengantisipasi gejolak ekonomi dan moneter. Oleh karena itu peningkatan pembangunan peternakan harus dilakukan secara terus menerus berkesinambungan yang pada akhirnya akan meningkatkan kesejahteraan petani peternak. Untuk meningkatkan pembangunan peternakan saat ini pola pendekatan pembangunan melalui pengembangan kawasan agribisnis berbasis peternakan.

Agar dapat memberikan solusi bagi rumusan permasalahan, maka kegiatan studi pengembangan kawasan berbasis peternakan di Kabupaten Pamekasan ini bertujuan untuk: (1) Memetakan sebaran kawasan peternakan di Kabupaten Pamekasan berdasarkan jenis ternak dan 
letak geografisnya; (2) Mengumpulkan dan menganalisa data perkembangan usaha peternakan di Kabupaten Pamekasan; (3) Mengidentifikasi permasalahan dalam menjalankan dan mengembangkan usaha peternakan; (4) Menganalisa kawasan yang berpotensi untuk dikembangkan menjadi kawasan berbasis peternakan.

\section{METODE}

Penelitian ini dilakukan pada bulan April-Juni 2017 berlokasi di Kabupaten Pamekasan dengan letak koordinat

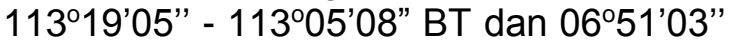
- 07031'17' LS. Kerangka pendekatan dalam penelitian ini didasarkan pada pengembangan ternak sapi potong sebagai usaha pertanian berbasis lahan (land base agriculture), dimana lahan merupakan faktor penting sebagai tempat hidup dan penghasil hijauan makanan ternak. Usaha ternak sapi potong (ruminasia pada umumya) terkait erat dengan usaha tani secara umum. Lahanlahan usaha tani tersebut mempunyai kemampuan yang berbeda dalam menyediakan hijauan makanan ternak karena perbedaan jenis tanaman dan pengelolaan.

Penentuan potensi lahan untuk pengembangan sapi potong dengan evaluasi kesesuaian lahan untuk lingkungan ekologis sapi potong dan kesesuaian lahan tanaman sumber hijauan makanan ternak yang dominan dan berpotensi dikembangkan di lokasi penelitian. Kesesuaian lahan untuk hijauan makanan ternak dicerminkan oleh tingkat ketersediaan hijauan makanan pada suatu wilayah. Identifikasi dan analisis data yang dilakukan adalah (1) identifikasi jenis penggunaan lahan yang berpotensi untuk pengembangan sapi potong, (2) penilaian kesesuaian lingkungan ekologis sapi potong, (3) penilaian kesesuaian lahan untuk tanaman hijauan makanan ternak, (4) tingkat ketersediaan hijauan makanan ternak, (5) prioritas arahan lahan, dan (6) analisis wilayah untuk arahan kawasan penyebaran dan pengembangan. Analisis spasial dan penyajian hasil dilakukan dengan pendekatan Sistem Informasi Geografi (SIG) dengan menggunakan software utama Arcview 3.3 dan ArcGIS 9.3.

Alat-alat yang digunakan dalam penelitian ini antara lain: seperangkat komputer dengan software utama Arcview 3.3, ArCGIS 9.3 dan program pendukung lainnya, citra satelit, peta rupa bumi Kabupaten Pamekasan skala 1:25.000 dan GPS (Global Positioning System). Komputer dengan software pendukung SIG digunakan untuk pengolahan data atribut dan peta-peta digital.

Tabel 1. Data-data yang Diperlukan

\begin{tabular}{|l|c|c|}
\hline No & Jenis/Tipe Data & Sumber \\
\hline 1 & $\begin{array}{c}\text { Peta Rupa Bumi Indonesia (RBI) } \\
\text { wilayah Kabupaten Pamekasan Skala } \\
1: 250.000 \text { atau 1:25.000 }\end{array}$ & Badan Informasi Geospasial (BIG) \\
\hline 2 & $\begin{array}{c}\text { Citra satelit resolusi tinggi/menengah } \\
\text { (IKONOS, Landsat, ALOS) }\end{array}$ & Badan Informasi Geospasial (BIG) \\
\hline 3 & Data kualitas/karakteristik lahan & Badan Informasi Geospasial (BIG) \\
\hline 4 & Data iklim/ curah hujan & BMKG \\
\hline 5 & $\begin{array}{c}\text { Data populasi ternak (ruminansia dan } \\
\text { unggas) Kabupaten Pamekasan }\end{array}$ & BPS Kabupaten Pamekasan \\
\hline 6 & Data komposisi dan nilai Satuan Ternak \\
(ST) ruminansia Kabupaten Pamekasan & BPS Kabupaten Pamekasan \\
\hline 8 & Data luas panen tanaman pangan & BPS Kabupaten Pamekasan \\
\hline
\end{tabular}




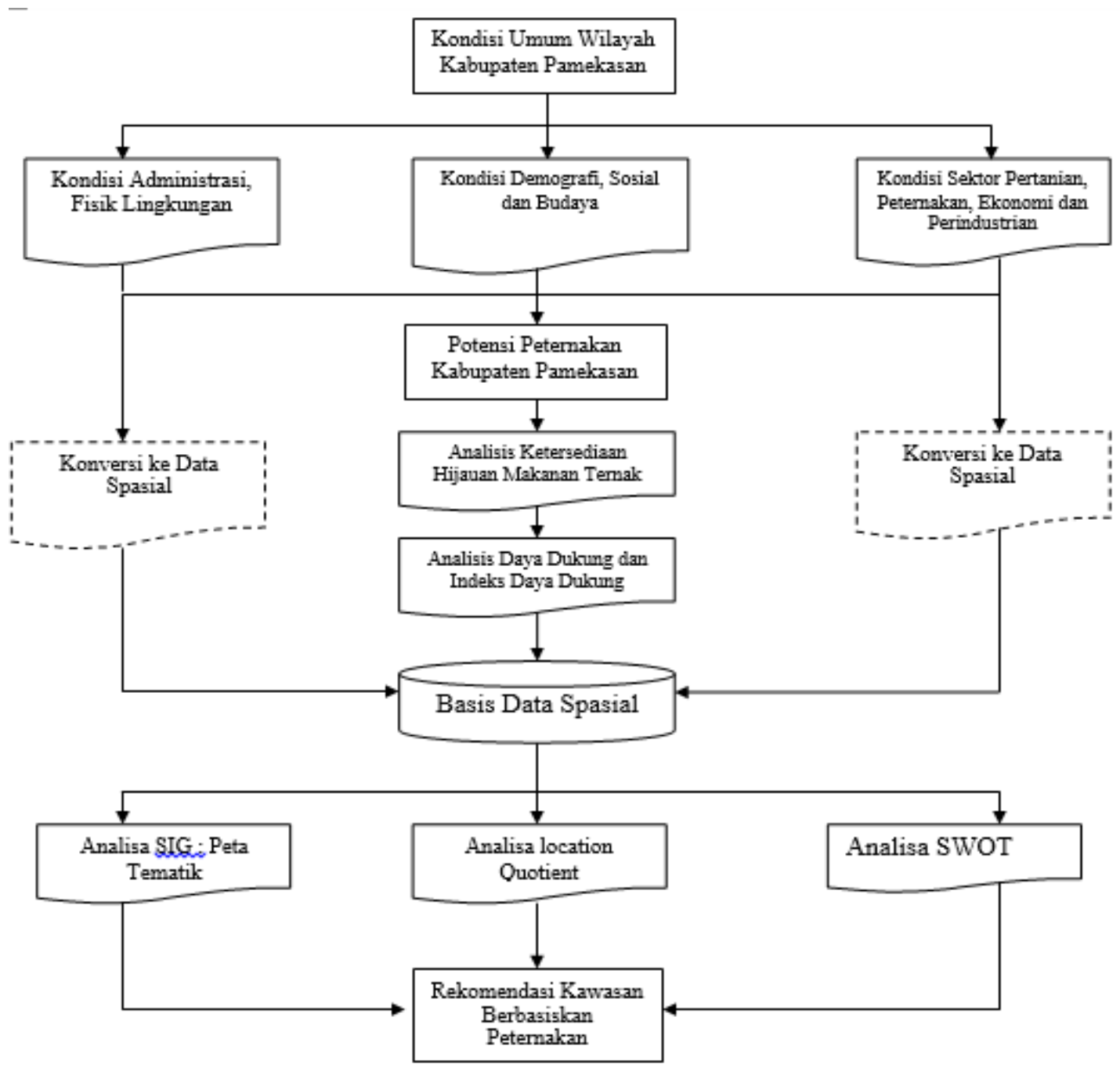

Gambar 1. Alur Pengolahan Data

\section{- Analisa Data}

1. Penilaian Kesesuaian Lingkungan

Kesesuaian lingkungan ekologis untuk peternakan mengikuti metode evaluasi yang dikembangkan oleh Ashari et al. (1995). Peta tematik kesesuaian lingkungan ekologis sapi potong diperoleh dari hasil joint tabel dan query antara data karakteristik (atribut) peta satuan lahan dengan data kriteria kesesuaian lingkungan ekologis sapi potong. Penilaian kesesuaian lingkungan dilakukan secara matching antara kualitas/karakteristik lahan dengan kriteria persyaratan lingkungan ekologis sapi potong, dalam hal ini penilaian dilakukan untuk pemeliharaan sapi potong sistem kandang. Penilaian dilakukan pada tingkat ordo yaitu: $S$ Sesuai) dan N (Tidak Sesuai) berdasarkan kriteria yang dihasilkan Tim Peneliti Daya Dukung Lahan Peternakan Puslittanak, yaitu Suratman et al. (1998).

Daya dukung hijauan makanan ternak adalah kemampuan suatu wilayah untuk menghasilkan pakan ternak terutama berupa hijauan yang dapat dihasilkan bagi kebutuhan sejumlah populasi sapi potong dalam bentuk segar maupun kering, tanpa melalui pengolahan dan tanpa pengolahan khusus dan diasumsikan penggunaannya hanya untuk sapi potong.

Daya dukung hijauan dihitung berdasarkan produksi bahan kering (BK) terhadap kebutuhan satu satuan ternak (1 ST) sapi potong dalam satu tahun, dimana kebutuhan bahan kering adalah 6.25 $\mathrm{Kg} /$ hari atau $2.28 \mathrm{Ton} / \mathrm{tahun}$ (NRC, 1984), untuk sapi dengan berat hidup mencapai 
$500 \mathrm{~kg}$. Untuk ternak sapi di Indonesia pada umumnya tiap 1 ST memiliki kisaran berat hidup $200-250 \mathrm{~kg}$. Jadi kebutuhan pakan/bahan kering minimum untuk 1 ST selama satu tahun dapat berbeda-beda, tergantung berat hidup sapinya. Kebutuhan pakan minimum ternak ruminansia per satu satuan ternak (1 ST) dihitung menurut Sumanto dan Juarini (2006) sebagai berikut :

$\mathrm{K}=2.5 \% \times 50 \% \times 365 \times 250 \mathrm{~kg}=1.14$ ton BKC/tahun/ST

Keterangan :

- $\mathrm{K}$ : kebutuhan pakan minimum untuk 1 ST dalam ton bahan kering tercerna selama satu tahun.

- 2.5\% : kebutuhan minimum jumlah ransum hijauan pakan (bahan kering) terhadap berat badan.

- $50 \%$ : Nilai rata-rata daya cerna berbagai jenis tanaman.

- 365 : jumlah hari dalam 1 tahun

- $250 \mathrm{~kg}$ : berat hidup 1 ST.

Produksi bahan kering merupakan jumlah dari produksi pakan asal limbah pertanian dan produksi pakan dari hijauan alami. Jumlah potensi limbah dari masingmasing tanaman pangan merupakan potensi ketersediaan pakan potensial saat ini. Perhitungan pakan asal limbah pertanian per kecamatan dihitung menurut Pedoman Identifikasi Wilayah (Sumanto dan Juarini 2006). Hasil perhitungan produksi bahan kering selanjutnya digunakan untuk mendapatkan daya dukung pakan hijauan dengan menggunakan persamaan sebagai berikut (Haryanto et al. 2002):

Daya Dukung (ST) $=$ Produksi Bahan Kering $(\mathrm{kg}) /$ Kebutuhan Bahan Kering Sapi Dewasa $(\mathrm{kg} / \mathrm{ST})$

Satuan ternak (ST) adalah satuan untuk populasi ternak ruminansia yang diperoleh dari jumlah populasi dikalikan dengan faktor konversi, untuk ternak sapi faktor konversinya adalah 0.7 (Ashari et al. 1995) Untuk mewakili populasi sapi yang terdiri dari induk betina, induk jantan, dan anak dengan berbagai tingkatan umur, maka populasi sapi keseluruhan dikali dengan 0.7. Indeks Daya Dukung (IDD) hijauan makanan ternak dihitung dari jumlah produksi hijauan makanan ternak yang tersedia terhadap jumlah kebutuhan hijauan bagi sejumlah populasi ternak ruminansia di suatu wilayah. Indeks Daya Dukung dihitung berdasarkan bahan kering dengan persamaan sebagai berikut (Ashari et al. 1995) :

IDD Hijauan

$=\frac{\text { Total Produksi Bahan Kering }(\mathrm{Kg})}{\text { Jumlah Populasi Ruminansia x Kebutuhan BK Sapi }}$

Berdasarkan nilai indeks daya dukung diperoleh kriteria status daya dukung hijauan seperti pada Tabel 2. Indeks daya dukung mencerminkan tingkat keamanan pakan pada suatu wilayah, untuk mendukung kehidupan ternak yang berada di atasnya.

Tabel 2. Status Daya Dukung (IDD)

\begin{tabular}{|c|c|c|}
\hline No & IDD & Kriteria \\
\hline 1 & $>2$ & Aman \\
\hline 2 & $1.5-2$ & Rawan \\
\hline 3 & $1-1.5$ & Kritis \\
\hline 4 & $<1$ & Sangat \\
\hline
\end{tabular}

Produksi hijauan merupakan produksi relatif untuk masing-masing kelas kesesuaian lahan disebut juga perkiraan persentase produktivitas, dimana untuk kelas S1 $=80-100 \%$, S2 $=60-80 \%$ dan S3 $=41-60 \%$, dari produksi rata-rata masingmasing hijauan atau daya dukung lahan, sedangkan kelas $\mathrm{N}$ tidak diperhitungkan karena persentasinya sangat rendah $(<20 \%)$ (Hardjowigeno dan Widiatmaka 2001). Pola ketersediaan hijauan di lahan sawah bersifat lebih fluktuatif dibandingkan pada lahan lainnya, karena dipengaruhi oleh pola tanam dan musim tanam, sehingga ketersediaan hijauan bersifat dinamik.

Analisis spasial untuk mengetahui sebaran tingkat ketersediaan hijauan makanan ternak dengan menggunakan pendekatan SIG.

\section{HASIL PEMBAHASAN Identifikasi Lahan}

Lahan lahan yang potensial untuk pengembangan peternakan khususnya untuk ternak sapi potong di peroleh dari 


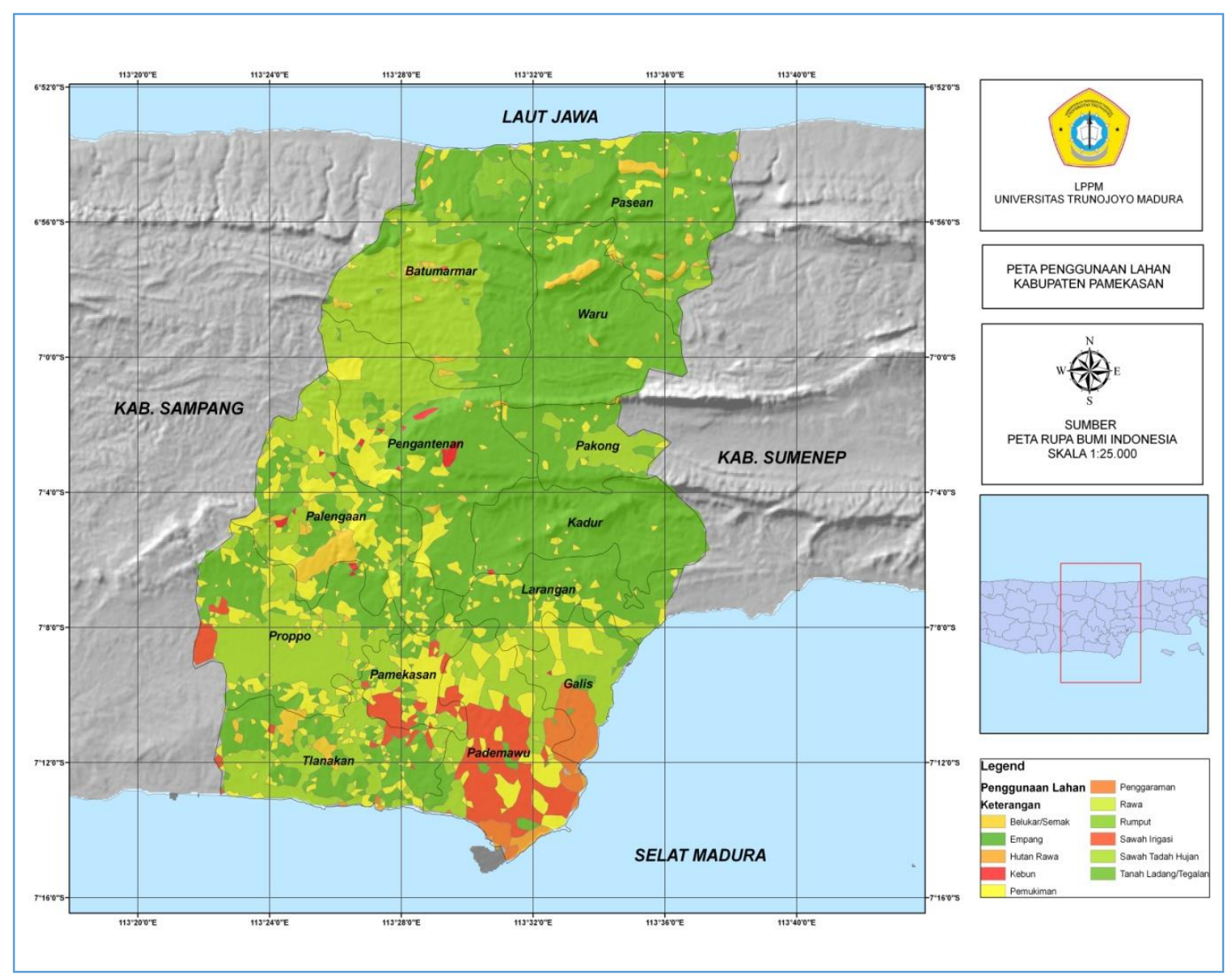

Gambar 2. Peta Penggunaan Lahan Kabupaten Pamekasan

data BAPPEDA Kabupaten Pamekasan (2012) tentang jenis dan luas pengunaan lahan (Gambar 2).

Jenis atau tipe lahan yang dapat dikembangkan menjadi lahan-lahan potensial untuk peternakan sapi potong adalah lahan pertanian pada umumnya, hutan dan tegalan dengan luas keseluruhan adalah $49.284,78 \mathrm{Ha}$ atau sekitar $62 \%$ dari total luas penggunaan lahan di Kabupaten Pamekasan. Sementara itu, lahan-lahan yang sulit dikembangkan untuuk pengembangan peternakan di Kabupaten Pamekasan adalah lahan pemukiman, pemakaman, perdagangan, industri, tambak garam dan tanah tandus dengan luas 29.945,23 Ha. Gambar 2 menggambarkan mengenai sebaran penggunaan lahan di Kabupaten Pamekasan. Untuk jenis lahan-lahan yang potensial, yang paling luas adalah tegalan dengan total luas mencapai 32.958,75 Ha atau sekitar $66.87 \%$ dan tersesebar di seluruh kecamatan. Selain itu, sawah tadah hujan juga memiliki luas yang cukup potensial yaitu sekitar 8.569 Ha juga tersebar di seluruh kecamatan.

Jenis lahan tegalan mendominasi tipe lahan yang potensial untuk dikembangkan sebagai kawasan peternakan di Kabupaten Pamekasan (Tabel 3). Kecamatan yang memiliki luas tegalan terbesar adalah Kecamatan Batumarmar dan Pasean dengan luas diatas $4.000 \mathrm{Ha}$. Kemudian diikuti oleh Kecamatan Palengaan dan Pegantenan dengan luas mencapai lebih dari $3.700 \mathrm{Ha}$. Untuk jenis lahan sawah tadah hujan, wilayah kecamatan dengan luas terbesar terdapat di Kecamatan Proppo $(2.220 \mathrm{Ha})$ dan Kecamatan Batumarmar (2.580 Ha). Untuk sawah semi tadah hujan, lahan terluas terdapat di Kecamatan Pademawu (1.847 Ha). 
Tabel 3. Luas dan Sebaran Lahan Potensi Peternakan Menurut Penggunaan Lahan

\begin{tabular}{|c|l|r|r|r|r|r|}
\hline No & \multicolumn{1}{|c|}{ Kecamatan } & \multicolumn{1}{c|}{ Sawah Irigasi } & Sawah Semi & \multicolumn{1}{c|}{ Sawah Tadah } & \multicolumn{1}{c|}{ Tegalan } & Hutan Sejenis \\
\hline 1 & Tlanakan & 114.00 & 14.03 & 733.00 & $2,129.60$ & 338.00 \\
\hline 2 & Pademawu & - & $1,857.00$ & 951.00 & $2,287.42$ & 238.00 \\
\hline 3 & Galis & 578.00 & 72.00 & 257.00 & 891.39 & 269.00 \\
\hline 4 & Larangan & - & 497.00 & 241.00 & $1,924.53$ & - \\
\hline 5 & Pamekasan & - & 370.00 & 158.00 & $1,147.78$ & - \\
\hline 6 & Proppo & - & 284.00 & $2,220.00$ & $2,570.87$ & - \\
\hline 7 & Palengaan & - & 258.00 & 336.00 & $3,725.28$ & - \\
\hline 8 & Pegantenan & - & 280.00 & 15.00 & $3,790.97$ & - \\
\hline 9 & Kadur & - & 186.00 & 11.00 & $2,483.56$ & - \\
\hline 10 & Pakong & 694.00 & 600.00 & 354.00 & 215.29 & 219.00 \\
\hline 11 & Waru & - & 553.00 & 586.00 & $2,270.59$ & 94.00 \\
\hline 12 & Batumarmar & - & 115.00 & $2,580.00$ & $4,882.10$ & - \\
\hline 13 & Pasean & - & 127.00 & 127.00 & $4,639.37$ & - \\
\hline & Total & $1,386.00$ & $5,213.03$ & $8,569.00$ & $32,958.75$ & $1,158.00$ \\
\hline
\end{tabular}

Tabel 4. Luas dan Sebaran Lahan Potensi Peternakan Menurut Kelerengan

\begin{tabular}{|l|r|r|r|r|r|}
\hline \multicolumn{1}{|c|}{ Kecamatan } & \multicolumn{1}{c|}{$\mathbf{0 - 1 5}$} & \multicolumn{1}{c|}{$\mathbf{1 5 - 2 5}$} & $\mathbf{2 5 - 4 0}$ & \multicolumn{1}{c|}{$>$ 40 } & \multicolumn{1}{c|}{ Jumlah } \\
\hline Tlanakan & $\mathbf{4 , 8 1 0}$ & - & - & - & $\mathbf{4}, 810$ \\
\hline Pademawu & $\mathbf{7 , 1 8 9}$ & - & - & - & $\mathbf{7}, 189$ \\
\hline Galis & 3,186 & - & - & - & 3,186 \\
\hline Larangan & 3,841 & 245 & - & - & 4,086 \\
\hline Pamekasan & 2,647 & - & - & - & 2,647 \\
\hline Proppo & 6,882 & 267 & - & - & 7,149 \\
\hline Palengaan & 6,830 & 1,880 & 138 & - & 8,848 \\
\hline Pegantenan & 5,733 & 1,873 & 513 & 485 & 8,604 \\
\hline Kadur & 3,376 & 272 & 638 & 956 & 5,242 \\
\hline Pakong & 1,993 & 532 & 113 & 433 & 3,071 \\
\hline Waru & 4,774 & 1,509 & - & 720 & 7,003 \\
\hline Batumarmar & 3,308 & 5,808 & 463 & 128 & 9,707 \\
\hline Pasean & 5,395 & 1,905 & 388 & - & 7,688 \\
\hline Jumlah & 59,964 & 14,291 & 2,253 & 2,722 & 79,230 \\
\hline
\end{tabular}

Faktor penghambat kesesuaian lahan pada umumnya, baik untuk lingkungan ekologis sapi potong maupun hijauan makan ternaknya adalah faktor lereng dan elevasi, kesuburan tanah terutama $\mathrm{pH}$ tanah dan air di sebagian wilayah yang cukup masam. Sebagian wilayah Kabupaten Pamekasan mempunyai kemiringan lereng yang agak curam sampai sangat curam ( $>40 \%)$, serta ketinggian yang sangat bervariasi. Nilai lereng dan elevasi yang semakin tinggi terkait dengan bahaya erosi yang semakin besar dan suhu udara yang semakin rendah, sehingga tidak sesuai untuk lingkungan ekologis sapi potong dan penanaman hijauan makanan ternak.

\section{Kondisi Peternakan}

Pada subsektor peternakan, usaha peternakan yang paling menonjol di Kabupaten Pamekasan adalah ternak besar (sapi), ternak sedang (kambing dan domba) dan ternak unggas (ayam buras/ras petelur dan itik). 
Tabel 5. Sebaran Populasi Ternak Sapi Potong di Kabupaten Pamekasan

\begin{tabular}{|r|l|r|r|}
\hline \multicolumn{1}{|l|}{ No } & Kecamatan & Populasi Sapi Potong & Prosentase \\
\hline 1 & Tlanakan & 10,652 & 8.34 \\
\hline 2 & Pademawu & 7,703 & 6.03 \\
\hline 3 & Galis & 2,147 & 1.68 \\
\hline 4 & Larangan & 7,821 & 6.13 \\
\hline 5 & Pamekasan & 3,525 & 2.76 \\
\hline 6 & Proppo & 13,606 & 10.66 \\
\hline 7 & Palengaan & 8,427 & 6.60 \\
\hline 8 & Pegantenan & 13,703 & 10.73 \\
\hline 9 & Kadur & 10,871 & 8.51 \\
\hline 10 & Pakong & 6,839 & 5.36 \\
\hline 11 & Waru & 13,841 & 10.84 \\
\hline 12 & Batumarmar & 11,068 & 8.67 \\
\hline 13 & Pasean & 17,471 & 13.68 \\
\hline & Jumlah & 127,674 & 100 \\
\hline
\end{tabular}

Berdasarkan penyebaran populasi ternak, maka ternak sapi potong di Kabupaten Pamekasan terdapat di pesisir utara. Khusus untuk usaha ternak sapi potong, mengalami peningkatan sekitar 2000 ekor dari tahun ke tahun. Usaha peternakan sapi di Kabupaten Pamekasan pada umumnya dilaksanakan dengan sistem kandang, karena lahan padang penggembalaan yang memadai tidak tersedia. Hijauan makanan ternak berupa rumput unggul umumnya sudah ditanam sendiri oleh peternak, sebagian besar dicampur dengan tanaman pertanian di kebun, ladang/tegalan atau sawah mereka. Teknis budidaya dan manajemen beternak sapi sudah diterapkan dengan cukup baik, terlihat dari pakan yang diberikan, pemilihan bibit yang lebih cenderung dengan sistem Inseminasi Buatan dan pengetahuan tentang kesehatan ternak. Kelembagaan peternak juga sudah berkembang, dengan membentuk kelompok petani peternak. Kelompok ini ada yang berkembang menjadi koperasi atau wadah yang dapat menyalurkan kebutuhan sarana produksi peternakan.

\section{Kesesuaian Lahan Tanaman Hijau untuk Ternak}

Hasil klasifikasi dan pengolahan peta serta setelah dilakukan pengecekan lapangan, diperoleh sembilan jenis tanaman sebagai sumber hijauan makanan ternak yang dominan dan yang berpotensi untuk dikembangkan, yaitu rumput unggul seperti rumput Gajah dan Setaria, rumput alam, leguminosa, padi sawah, jagung, ubi kayu, ubi jalar dan kacang tanah. Rumput alam (rumput lapangan) dengan pendekatan penilaian terhadap padang penggembalaan (pasture). Rumput alam merupakan jenis tanaman sumber hijauan yang dominan dikebun kelapa.

a. Rumput unggul, dengan pendekatan penilaian kesesuaian lahan untuk rumput gajah (Pennisetum purpureum) dan rumput setaria (Setaria spachelata).

b. Tanaman pangan yang dominan diusahakan di lahan sawah, yaitu : padi, jagung, kedelai, kacang tanah, kacang hijau, ubi kayu dan ubi jalar.

c. Leguminosa sebagai penilaian untuk leguminosa pada umumnya dan untuk tanaman sumber hijauan pada kebun campuran, lahan semak dan rerumputan, tegalan dan hutan produksi.

Tanaman sebagai sumber hijauan makanan ternak di Kabupaten Paemkasan ditanam dalam bentuk usaha pertanian multikultur, dalam satu lahan bisa terdiri dari berbagai tanaman. Lahan 
tegalan/ladang misalnya, terdiri dari tanaman jagung, kacang tanah, legum, ubi kayu, sedikit padi dan rumput alam. Pada lahan-lahan yang lain, seperti lahan perkebunan yang ditanami karet, gambir, kelapa, kopi, dan coklat, yang dapat juga diselingi tanaman lain di dalamnya, juga lahan semak/rerumputan yang terdapat di dalamnya tanaman pertanian, rumput alam, legum dan sebagainya. Demikian juga dengan lahan kebun campuran dan lain-lain, kecuali lahan sawah yang hanya terdiri dari tanaman padi (monokultur). Berdasarkan hasil penilaian secara matching antara kualitas/karakteristik lahan dengan persyaratan tumbuh tanaman hijauan makanan ternak menghasilkan kelas kesesuaian lahan setiap jenis tanaman sumber hijauan makanan ternak yang dinilai. Hasil yang diperoleh tersebut merupakan basis data untuk analisis spasial dan pembuatan peta kesesuaian lahan dengan pendekatan SIG.

Proses SIG yang dilakukan adalah joint tabel basis data dengan tabel data atribut peta digital satuan lahan dan query berdasarkan kelas kesesuaian lahan. Hasil penilaian menunjukkan bahwa faktor penghambat utama yang dominan di lahan-lahan di Kabupaten Pamekasan adalah erosi (e) dan retensi hara (f). Faktor erosi disebabkan oleh sebagian besar wilayah Kabupaten Lima Puluh Kota mempunyai lereng > 40\% yang berupa perbukitan dan pegunungan, sedangkan faktor retensi hara disebabkan $\mathrm{pH}$ air dan tanah sebagian besar bersifat masam. Usaha-usaha perbaikan yang dapat dilakukan diantaranya dengan penambahan kapur untuk mengurangi kemasaman tanah dan air dan usahausaha konservasi tanah untuk mencegah/mengurangi bahaya erosi. Dalam menentukan usaha-usaha perbaikan tersebut diperlukan perhitungan biaya dan manfaat yang cermat sehingga dapat diketahui kelayakannya untuk dilaksanakan.

\section{Daya Dukung Hijauan Makanan Ternak}

Ketersediaan hijauan makanan ternak dapat diketahui berdasarkan daya dukung hijauan dan indeks daya dukung. Perhitungan luas, nilai daya dukung, indeks daya dukung, jenis penggunaan lahan, dan pembuatan peta dengan pendekatan SIG, yaitu dengan proses joint tabel basis data dengan tabel data atribut peta digital satuan lahan, dilanjutkan query untuk membuat peta status daya dukung. Basis data awal yang dibutuhkan antara lain kelas kesesuaian lahan masingmasing jenis tanaman yang diperhitungkan, tingkat kepadatan ekonomi ternak sapi yang dihitung berdasarkan jumlah satuan ternak (ST) per seribu penduduk (ST/1000 jiwa) (Sumanto dan Juarini, 2006).

Kepadatan ekonomi ternak sapi di Kabupaten Pamekasan seperti terdapat pada Tabel 6. Nilai kepadatn ekonomi ternak sapi potong di Kabupaten Pamekasan dihitung berdasarkan proporsi antara nilai ST (Satuan Ternak) untuk setiap 1000 orang penduduk. Hasilnya didapatkan bahwa nilai kepadatan ekonomi tertinggi dapat ditemui di Kabupaten Pasean, Pegantenan dan Proppo. Indeks daya dukung hijauan makanan ternak dapat menggambarkan status daya dukung makanan ternak pada masingmasing kecamatan, apakah tergolong aman, rawan, kritis atau sangat kritis.

Sumberdaya lahan yang dapat dimanfaatkan oleh peternak antara lain: lahan sawah, padang penggembalaan, lahan perkebunan, dan hutan rakyat, dengan tingkat kepadatan tergantung kepada keragaman dan intensitas tanaman, ketersediaan air, jenis sapi potong yang dipelihara. Luasnya lahan sawah, kebun, dan hutan tersebut memungkinkan pengembangan pola integrasi ternak-tanaman yang merupakan suatu proses saling menunjang dan saling menguntungkan, melalui pemanfaatan tenaga sapi untuk mengolah tanah dan kotoran sapi sebagai pupuk organik. Sementara lahan sawah dan lahan tanaman pangan menghasilkan jerami padi dan hasil sampingan tanaman yang dapat diolah sebagai makanan sapi. tanaman lain. Pemanfaatan pola integrasi diharapkan dapat meningkatkan ketersediaan pakan sepanjang tahun, sehingga dapat meningkatkan produksi dan produktivitas ternak (Riady 2004). Sedangkan kebun dan hutan memberikan sumbangan rumput alam dan jenis 
Tabel 6. Perhitungan Nilai Kepadatan Ekonomi Ternak Sapi

\begin{tabular}{|c|l|r|r|r|r|}
\hline No & \multicolumn{1}{|c|}{ Kecamatan } & Populasi Sapi Potong & Faktor Konversi & Nilai ST & Kepadatan Ekonomi ST \\
\hline 1 & Tlanakan & 10,652 & 0.7 & $7,456.40$ & 7.46 \\
\hline 2 & Pademawu & 7,703 & 0.7 & $5,392.10$ & 5.39 \\
\hline 3 & Galis & 2,147 & 0.7 & $1,502.90$ & 1.50 \\
\hline 4 & Larangan & 7,821 & 0.7 & $5,474.70$ & 5.47 \\
\hline 5 & Pamekasan & 3,525 & 0.7 & $2,467.50$ & 2.47 \\
\hline 6 & Proppo & 13,606 & 0.7 & $9,524.20$ & 9.52 \\
\hline 7 & Palengaan & 8,427 & 0.7 & $5,898.90$ & 5.90 \\
\hline 8 & Pegantenan & 13,703 & 0.7 & $9,592.10$ & 9.59 \\
\hline 9 & Kadur & 10,871 & 0.7 & $7,609.70$ & 7.61 \\
\hline 10 & Pakong & 6,839 & 0.7 & $4,787.30$ & 4.79 \\
\hline 11 & Waru & 13,841 & 0.7 & $9,688.70$ & 9.69 \\
\hline 12 & Batumarmar & 11,068 & 0.7 & $7,747.60$ & 7.75 \\
\hline 13 & Pasean & 17,471 & 0.7 & $12,229.70$ & 12.23 \\
\hline
\end{tabular}

Tabel 7. Nilai Konversi Perhitungan Potensi Limbah dari Produksi Panen

\begin{tabular}{|c|l|c|}
\hline No & $\begin{array}{c}\text { Jenis Produksi } \\
\text { Panen }\end{array}$ & Nilai Konversi \\
\hline 1 & Padi Sawah (PS) & 0.4 \\
\hline 2 & Padi Ladang (PL) & 0.4 \\
\hline 3 & Jagung (J) & 0.5 \\
\hline 4 & Kedelai (KD) & 0.55 \\
\hline 5 & Kacang (KC) & 0.55 \\
\hline 6 & Ubi Jalar (UJ) & 0.25 \\
\hline 7 & Ubi Kayu & 0.25 \\
\hline \multicolumn{2}{|c|}{ Persamaan } & $(\mathrm{PS} \times 0.4)+(\mathrm{PL} \times 0.4 \times 3)+(\mathrm{J} \times 3 \times 0.5)+(\mathrm{KD} \times 3 \times 0.55)+((\mathrm{KH}+\mathrm{KT}) \times 2 \times 0$ \\
\multicolumn{2}{|c|}{} & $.550)+((\mathrm{UJ} \times 0.25 / 6))+((\mathrm{UK \times 0.25/4)}) \times 0.65$ \\
\hline
\end{tabular}

vegetasi alam yang tumbuh di areal perkebunan dapat dikonsumsi ternak dan dapat dikelompokkan sebagai hijauan, bukan sebagai gulma. Integrasi ternak dengan perkebunan bertujuan untuk mendapatkan nilai tambah lahan berupa produk ternak. Dengan tujuan seperti ini, perbaikan ketersediaan hijauan di areal perkebunan merupakan target yang sejalan dengan upaya pencapaian tingkat produktivitas ternak.

Perhitungan nilai daya dukung ada dua bagian yaitu potensi limbah dan potensi hijauan alami. Potensi limbah didapat dari sisa hasil produksi tanaman pangan seperti jerami padi sawah, padi ladang, jagung, kacang kedelai, kacang hijau dan kacang tanah. Sedangkan potensi hijauan alami di dapat dari luas perkebunan dan luas penggunaan lahan seperti pekarangan, tegalan, huma, ladang, kebun, lahan bera, penggembalaan, hutan rakyat dan lain-lain. Tabel 8 dan 9 menjelaskan tentang perhitungan produksi panen hijauan di
Kabupaten Pamekasan dan perkiraan limbah hijauan yang dihasilkan pada periode tahun 2016. Berdasarkan hasil perhitungan, maka limbah hijauan terbesar yang dapat digunakan sebagai sumber makanan ternak berasal dari padi sawah dan padi ladang. Hal ini bisa dimaklumi sebab kedua komoditas inilah yang dominan di seluruh kecamatan di Kabupaten Pamekasan.

Total potensi hijauan sebagai bahan baku makan ternak dapat diketahui dari jumlah produksi hijauan alami dan potensi limbah hijauan. Produksi hijauan alami dihitung dari total produksi panen seluruh komoditi pertanian di Kabupaten Pamekasan (Tabel 8). Selanjutnya menurut Herlinda (2007), nilai produksi alami berkisar antara $55-60 \%$ dari total 
Tabel 8. Hasil Konversi Potensi Limbah

\begin{tabular}{|r|l|r|r|r|r|r|r|r|}
\hline No & Kecamatan & $\begin{array}{c}\text { Padi Sawah } \\
\text { (ton) }\end{array}$ & $\begin{array}{r}\text { Padi Ladang } \\
\text { (ton) }\end{array}$ & $\begin{array}{c}\text { Jagung } \\
\text { (ton) }\end{array}$ & Ubi Kayu (ton) & $\begin{array}{c}\text { Ubi Jalar } \\
\text { (ton) }\end{array}$ & $\begin{array}{c}\text { Kedelai } \\
\text { (ton) }\end{array}$ & $\begin{array}{c}\text { Kacang } \\
\text { Hijau (ton) }\end{array}$ \\
\hline 1 & Tlanakan & 3,053 & 542 & 1,906 & 373 & 8 & 23 & 56 \\
\hline 2 & Pademawu & 8,083 & 3,952 & 2,758 & 759 & 16 & - & 147 \\
\hline 3 & Galis & 2,807 & 996 & 65 & 133 & 13 & - & 4 \\
\hline 4 & Larangan & 2,122 & 1,302 & 3,609 & 931 & 147 & 14 & 224 \\
\hline 5 & Pamekasan & 2,563 & 322 & 1,521 & 182 & 12 & - & 88 \\
\hline 6 & Proppo & 6,020 & 3,026 & 1,970 & 2,295 & 51 & - & 45 \\
\hline 7 & Palengaan & 916 & 1,874 & 10,056 & 1,249 & 195 & 1 & 13 \\
\hline 8 & Pegantenan & 1,019 & 4,440 & 3,812 & 503 & 24 & 62 & 8 \\
\hline 9 & Kadur & 644 & 874 & 5,879 & 493 & 43 & - & 19 \\
\hline 10 & Pakong & 4,837 & 1,053 & 874 & 285 & 101 & 63 & 15 \\
\hline 11 & Waru & 1,496 & 3,116 & 8,038 & 209 & 111 & - & 19 \\
\hline 12 & Batumarmar & 2,272 & 3,025 & 20,068 & 190 & 362 & - & 17 \\
\hline 13 & Pasean & 1,089 & 437 & 11,385 & 612 & 152 & - & 8 \\
\hline & Jumlah & 36,920 & 24,958 & 71,937 & 8,212 & 1,231 & 162 & 662 \\
\hline
\end{tabular}

Tabel 9. Perhitungan Total Hijauan Untuk Makanan Ternak

\begin{tabular}{|r|l|r|r|r|r|}
\hline No & Kecamatan & $\begin{array}{c}\text { Jumlah Produksi } \\
\text { (ton) }\end{array}$ & $\begin{array}{c}\text { Produksi Hijauan } \\
\text { Alami (ton) }\end{array}$ & $\begin{array}{c}\text { Potensi Limbah } \\
\text { Hijauan (ton) }\end{array}$ & $\begin{array}{l}\text { Total Potensi } \\
\text { Hijauan (ton) }\end{array}$ \\
\hline 1 & Tlanakan & 14,463 & $8,677.80$ & $3,873.55$ & $12,551.35$ \\
\hline 2 & Pademawu & 38,966 & $23,379.60$ & $10,213.91$ & $33,593.51$ \\
\hline 3 & Galis & 10,225 & $6,135.00$ & $2,610.99$ & $8,745.99$ \\
\hline 4 & Larangan & 20,518 & $12,310.80$ & $5,426.04$ & $17,736.84$ \\
\hline 5 & Pamekasan & 11,190 & $6,714.00$ & $3,047.17$ & $9,761.17$ \\
\hline 6 & Proppo & 36,016 & $21,609.60$ & $8,713.54$ & $30,323.14$ \\
\hline 7 & Palengaan & 32,880 & $19,728.14$ & $9,295.67$ & $29,023.81$ \\
\hline 8 & Pegantenan & 23,507 & $14,104.20$ & $6,414.07$ & $20,518.27$ \\
\hline 9 & Kadur & 17,733 & $10,639.80$ & $5,168.96$ & $15,808.76$ \\
\hline 10 & Pakong & 18,158 & $10,894.80$ & $4,698.01$ & $15,592.81$ \\
\hline 11 & Waru & 28,914 & $17,348.40$ & $8,441.42$ & $25,789.82$ \\
\hline 12 & Batumarmar & 55,616 & $33,369.60$ & $16,856.68$ & $50,226.28$ \\
\hline 13 & Pasean & 29,652 & $17,791.20$ & $8,893.01$ & $26,684.21$ \\
\hline & Jumlah & 337,838 & 202,703 & 93,653 & 296,356 \\
\hline
\end{tabular}

produksi panen, dengan asumsi bahwa lahan-lahan pertanian di Kabupaten Pamekasan merupakan lahan dengan tingkat kesesuian sedang (S2). Berdasarkan tabel diatas, maka total potensi hijauan sebagai bahan baku makan ternak dapat diketahui dari jumlah produksi hijauan alami dan potensi limbah hijauan. Produksi hijauan alami dihitung dari total produksi panen seluruh komoditi pertanian di Kabupaten Pamekasan (Tabel 9). Selanjutnya menurut Herlinda (2007), nilai produksi alami berkisar antara 55-60\% dari total produksi panen, dengan asumsi bahwa lahan-lahan pertanian di Kabupaten Pamekasan merupakan lahan dengan tingkat kesesuian sedang (S2).
Wlayah yang memiliki potensi hijauan terbesar adalah Kecamatan Batumarmar yaitu sekitar 50.226 ton, diikuti oleh Kecamatan Pademawu dengan total sebesar 33.593 ton dan Kecamatan Proppo dengan total sebesar 30.323 ton. Sebaliknya, wilayah dengan total produksi hijauan terkecil adalah Kecamatan Galis (8.745 ton), Kecamatan Pamekasan (9.761 ton) dan Kecamatan Tlanakan (12.251 ton). Selanjutnya dilakukan perhitungan dengan membandingkan antara total produksi hijauan, kebutuhan pakan minimum ternak dalam 1 tahun dan jumlah ST (Satuan Ternak) di setiap kecamatan. Hasil perhitungannya adalah sebuah nilai indeks daya dukung (IDD) (Tabel 10). 
Tabel 10. Perhitungan Nilai Indeks Daya Dukung (IDD) untuk Kawasan Peternakan

\begin{tabular}{|r|l|r|r|r|r|r|r|r|}
\hline No & Kecamatan & $\begin{array}{c}\text { Potensi Limbah } \\
\text { Hijauan }\end{array}$ & $\begin{array}{c}\text { Produksi Hijauan } \\
\text { Alami }\end{array}$ & $\begin{array}{c}\text { Total } \\
\text { Produksi }\end{array}$ & $\begin{array}{c}\text { Kebutuhan Pakan } \\
\text { Minimum }\end{array}$ & \multicolumn{1}{c|}{ DD } & ST & IDD \\
\hline 1 & Tlanakan & $3,873.55$ & $8,677.80$ & $12,551.35$ & 0.9125 & $13,754.90$ & $7,456.40$ & 1.84 \\
\hline 2 & Pademawu & $10,213.91$ & $23,379.60$ & $33,593.51$ & 0.9125 & $36,814.80$ & $5,392.10$ & 6.83 \\
\hline 3 & Galis & $2,610.99$ & $6,135.00$ & $8,745.99$ & 0.9125 & $9,584.64$ & $1,502.90$ & 6.38 \\
\hline 4 & Larangan & $5,426.04$ & $12,310.80$ & $17,736.84$ & 0.9125 & $19,437.63$ & $5,474.70$ & 3.55 \\
\hline 5 & Pamekasan & $3,047.17$ & $6,714.00$ & $9,761.17$ & 0.9125 & $10,697.17$ & $2,467.50$ & 4.34 \\
\hline 6 & Proppo & $8,713.54$ & $21,609.60$ & $30,323.14$ & 0.9125 & $33,230.84$ & $9,524.20$ & 3.49 \\
\hline 7 & Palengaan & $9,295.67$ & $19,728.14$ & $29,023.81$ & 0.9125 & $31,806.91$ & $5,898.90$ & 5.39 \\
\hline 8 & Pegantenan & $6,414.07$ & $14,104.20$ & $20,518.27$ & 0.9125 & $22,485.78$ & $9,592.10$ & 2.34 \\
\hline 9 & Kadur & $5,168.96$ & $10,639.80$ & $15,808.76$ & 0.9125 & $17,324.67$ & $7,609.70$ & 2.28 \\
\hline 10 & Pakong & $4,698.01$ & $10,894.80$ & $15,592.81$ & 0.9125 & $17,088.01$ & $4,787.30$ & 3.57 \\
\hline 11 & Waru & $8,441.42$ & $17,348.40$ & $25,789.82$ & 0.9125 & $28,262.82$ & $9,688.70$ & 2.92 \\
\hline 12 & Batumarmar & $16,856.68$ & $33,369.60$ & $50,226.28$ & 0.9125 & $55,042.50$ & $7,747.60$ & 7.10 \\
\hline 13 & Pasean & $8,893.01$ & $17,791.20$ & $26,684.21$ & 0.9125 & $29,242.97$ & $12,229.70$ & 2.39 \\
\hline & Jumlah & $93,652.99$ & $202,702.94$ & $296,355.93$ & & & & \\
\hline
\end{tabular}

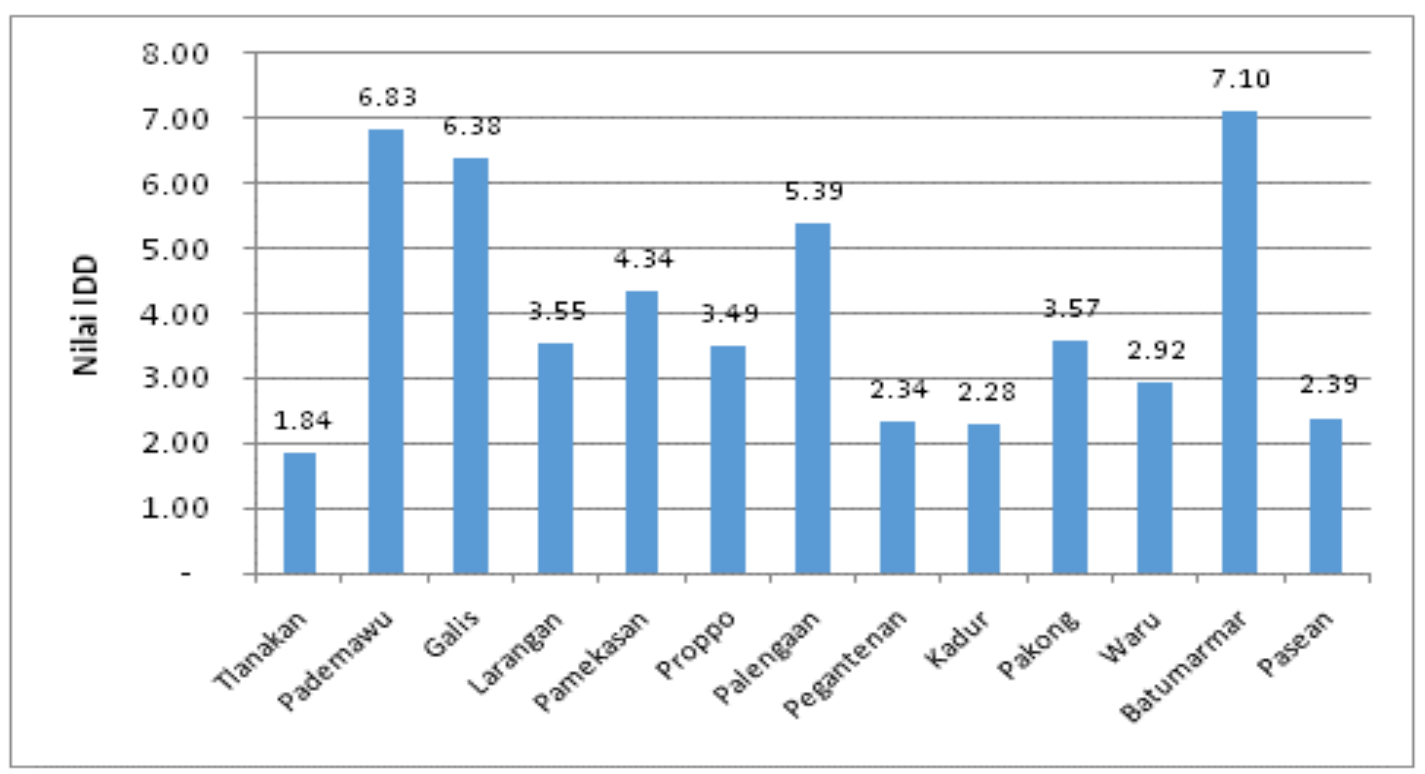

Gambar 3. Nilai IDD untuk Setiap Kecamatan di Kabupaten Pamekasan

Berdasarkan perhitungan nilai IDD, dari 13 kecamatan di Kabupaten Pamekasan, hanya 1 kecamatan yaitu Tlanakan yang memiliki status rawan (nilai IDD<2) untuk daya dukung peternakan. Sementara itu, wilayah kecamatan lainnya memiliki status aman (nilai IDD>2). Hal ini menunjukkan bahwa ternyata sebagian besar wilayah Kabupaten Pamekasan sesuai untuk dikembangkan sebagai kawasan peternakan bila ditinjau dari ketersediaan hijauan pakan (Tabel 10).

Selanjutnya berdasarkan Gambar 3, terlihat bahwa 4 wilayah kecamatan yang memiliki nilai IDD lebih dari 5 adalah Kecamatan Batumarmar (IDD=7.10), Pademawu (IDD=6.83), Galis (IDD=6.38) dan Palengaan (IDD=5.39). Dalam konteks pengembangan kawasan peternakan sapi potong di Kabupaten Pamekasan, ke-4 wilayah kecamatan inilah yang dapat direkomendasikan. Hal ini merupakan hasil perhitungan yang didasarkan pada ketersediaan pakan yang bersumber dari hijauan alami dan potensi limbah pertanian.

Pengembangan peternakan tidak mungkin dilakukan oleh Dinas Peternakan secara sendirian, akan tetapi perlu keterlibatan dari instansi lain dan stakeholder terkait sangat dibutuhkan. Dukungan pengembangan Kabupaten Pamekasan sangat kuat dari pemerintahan daerah untuk mengembangkan pertanian termasuk didalamnya peternakan. Kerjasama lintas sektoral sering terjadi 
terutama untuk pengembangan peternakan. Dinas Peternakan selalu berkoordinasi dengan Bappeda, Dinas Pertanian dan Dinas Koperasi dan UMKM serta lembaga-lembaga lain.

Menggunakan kekuatan yang dmiliki untuk memanfaatkan peluang yang ada dengan cara pembinaan dan pengembangan berdasarkan potensi wilayah. Kabupaten Pamekasan yang memiliki sumber daya alam yang melimpah cukup baik untuk pengembangan peternakan berdasarkan kondisi alam di setiap wilayah yang ada di Kabupaten Pamekasan. Pengembangan peternakan dapat dilakukan di kecamatan-kecamatan yang menjadi basis peternakan. Antara lain di Kecamatan Batumarmar, Pademawu dan Galis. Koordinasi lembaga yang cukup baik dan dukungan pemerintah terhadap peternakan dapat memacu pertumbuhan peternakan di daerah basis.

Menggunakan kekuatan yang dimiliki untuk mengatasi ancaman yang ada dapat dilaksanakan. Optimalisasi pemanfaatan dan pengamanan sumberdaya lokal. Sumber daya alam yang melimpah serta dukungan pemerintah yang kuat dapat mengatasi pengaruh buruk kondisi krisis global terutama ekonomi dengan memanfaatkan sumberdaya lokal. Dengan memanfaatkan sumber daya lokal maka kondisi sosial masyarakat akan merespon secara positif dengan adanya peternakan karena mereka dilibatkan dalam pengembangan ekonomi.

Menggunakan kekuatan yang dimiliki untuk mengatasi ancaman yang ada dapat dilaksanakan melalui pengembangan teknologi tepat guna dan peningkatan pembinaan dan pengembangan sumberdaya manusia peternakan. Kegiatan di sektor peternakan selama ini belum dapat memberikan kehidupan yang layak disebabkan oleh belum mempunyai produk peternakan merespon tuntutan konsumen saat ini yang menuntut kualitas tinggi. Pengembangan teknologi pascapanen dimaksudkan untuk menumbuhkan efisiensi dan memiliki nilai tambah. Pembinaan SDM harus lebih intensif lagi dan lebih menjangkau usaha peternakan yang menyebar.

Kondisi dimana subsektor peternakan berusaha meminimalkan ancaman untuk menghadapi ancaman. Pengembangan kemitraan yang lebih luas dan saling menguntungkan dan pemeriksaan kesehatan ternak secara kontinyu dan tindak pencegahan penyakit hewan. Upaya kemitraan dapat menolong produsen peternakan untuk mengatasi atau mengurangi tekanan dari berbagai ancaman dan kelemahan peternakan. Strategi pemeriksaan kesehatan ternak dilakukan untuk melindungi sumberdaya ternak agar tidak merugikan peternak. Strategi ini juga perlu dilaksanakan untuk menjamin produk yang (ASUH) selain itu untuk memenuhi tuntutan produk yang ASUH perlu dilakukan pengawasan pemotongan hewan.

Peternakan sapi merupakan sumber daya lokal masyarakat Madura pada umumnya dan lebih khusus masyarakat Kabupaten Pamekasan yang telah tumbuh kembang, membudaya dan terbukti memberikan sumbangan besar terhadap kesejahteraan masyarakat dan memberikankontribusi bagi peningkatan Pendapatan Asli Daerah (PAD). Kontribusi ternak sapi terhadap pengembangan sapi dan kebutuhan daging baik secara lokal maupun nasional sangatlah signifikan. Mengingat begitu besar tekad dan komitmen dalam upaya mewujudkan tercapainya Swasembada Daging Sapi secara nasional serta semakin besarnya kebutuhan akan daging sapi yang ASUH (Aman, Sehat, Utuh dan Higienis) maka perlu dilakukan beberapa hal :

a. Peningkatan jumlah populasi ternak besar khususnya sapi sebesar $10 \%$ setiap tahun.

b. Peningkatan jumlah induk sapi sebesar $30-40 \%$ dari populasi ternak sapi.

c. Peningkatan angka kelahiran pedet sebesar $75 \%$ dari jumlah induk.

d. Penurunan angka kematian pedet sebesar $10 \%$ dari jumlah sapi yang lahir.

e. Penurunan Pemotongan sapi betina produktif hingga $15 \%$ dari jumlah pemotongan sapi tercatat

f. Pengendalian pengeluaran ternak bibit.

g. Peningkatan produktivitas ternak melalui penyediaan pakan ternak sepanjang tahun.

h. Peningkatan teknologi pengolahan hasil peternakan. 
i. Peningkatan pengelolaan sumber daya alam lahan dan air.

j. Pengembangan peternakan melalui pola pengembangan dengan sistem So.

k. Penetapan kawasan pengembangan peternakan melalui perencanaan tata ruang padang pengembalaan.

I. Peningkatan sarana dan prasarana untuk pengembangan peternakan sapi.

$\mathrm{m}$. Membuka peluang seluas-luasnya bagi investasi dibidang peternakan sapi.

\section{KESIMPULAN}

1. Kabupaten Pamekasan merupakan wilayah dengan dukungan kondisi geografis dan sumber daya alam yang cukup dan berpotensi untuk perkembangan usaha peternakan dalam skala kecil dan menengah.

2. Hasil analisa menggunakan Indeks Daya Dukung (IDD) Hijauan untuk Makanan Ternak didapatkan kesimpulan bahwa 95\% kecamatan di Kabupaten Pamekasan memiliki status aman dalam hal dukungan pakan untuk pengembangan kawasan peternakan.

3. Berdasarkan nilai IDD, maka direkomendasikan bahwa wilayah yang sesuai untuk dikembangkan sebagai kawasan berbasis peternakan adalah Kecamatan Batumarmar, Galis dan Pademawu.

4. Berdasarkan hasil analisa SWOT, maka dapat direkomendasikan beberapa strategi yang bisa digunakan untuk mendukung perkembangan kawasan berbasis peternakan, yaitu : (1) pembinaan dan pengembangan berdasarkan potensi wilayah; (2) peningkatan dan pengembangan SDM peternak; (3) pengembangan kemitraan yang lebih luas dan saling menguntungkan; (4) pemeriksaan kesehatan ternak yang kontinyu; (5) pengembangan teknologi tepat guna; (6) optimalisasi dan pengamanan sumber daya lokal.

\section{DAFTAR PUSTAKA}

Ashari E, Juarini E, Sumanto, Wibowo B \& Suratman. 1995. Pedoman Analisis Potensi Wilayah Penyebaran. Balai Penelitian Ternak.

Faisal Y. 2006. Langkah Operasional Swasembada Daging 2010. Informasi Agribisnis Sinar Tani. Edisi 13-19 September 2006 No. 3167 Tahun XXXVII. Jakarta : Departemen Pertanian.

Herlinda S. 2007. Arahan Penataan Kawasan Penyebaran dan Pengembangan Ternak Sapi Potong di Kabupaten Limapuluh Kota. [Tesis]. Bogor (ID): Program Studi Ilmu Perencanaan Wilayah. Sekolah Pascasarjana IPB.

Kuswandi. 1995. Manfaat Nutrisi Lapangan dengan Tambahan Konsentrat pada Domba. ISPI Cabang Bogor.

Sitorus, S.S., Setiadi, B \& Martawidjaja, M. 1997. Pengaruh Penambahan Tetes dalam Ransum Terhadap Produktivitas Kambing Kacang. Balai Penelitian Ternak. Bogor.

$\begin{array}{crr}\text { Sumanto, Juarini } & \text { E. 2004. } & \text { Potensi } \\ \text { Kesesuaian } & \text { Lahan } & \text { untuk }\end{array}$ Pengembangan Ternak Ruminansia di Propinsi Nusa Tenggara Timur. Prosiding. Seminar Nasional Teknologi Peternakan dan Veteriner. Bogor 4-5 Agustus 2004. Bogor :Puslitbangnak, Balitbangtan. Hlm 123-129. 